\title{
Antinucleolar Autoantibody Induced by Mercuric Chloride in Mice: Does Sodium Selenite Inhibit Autoantibody Production?
}

\begin{abstract}
Repeated exposure of subtoxic doses of mercuric chloride $\left(\mathrm{HgCl}_{2}\right)$ can induce antinucleolar autoantibodies in susceptible mice. To study the immunopathological mechanism(s), sodium selenite $\left(\mathrm{Na}_{2} \mathrm{SeO}_{3}\right)$, which is known to reduce the toxicity of mercury, is injected simultaneously with $\mathrm{HgCl}_{2}$ into mice. Equimolar $\mathrm{Na}_{2} \mathrm{SeO}_{3}$ nor the same amount of $\mathrm{Se}$ in $\mathrm{Na}_{2} \mathrm{SeO}_{3}$ as $\mathrm{Hg}$ in $\mathrm{HgCl}_{2}$ could not reduce antinucleolar autoantibody induction by $\mathrm{HgCl}_{2}$. These results indicate that the mechanism of autoimmunity induction by $\mathrm{HgCl}_{2}$ might be independent of its toxicity.
\end{abstract}

Key words: $\mathrm{HgCl}_{2}-\mathrm{Na}_{2} \mathrm{SeO}_{3}-$ Antinucleolar autoantibody

Chronic exposure to metals and their compounds is associated with severe toxic effects. While often overlooked, several metals are frequently responsible for immunological reactions, resulting in allergic contact dermatitis and/or autoimmunity in individuals who come into contact with metal products occupationally1).

Experimental models of metal-induced hypersensitivity including autoimmunity have been developed. Repeated exposure to subtoxic doses of mercuric chloride $\left(\mathrm{HgCl}_{2}\right)$ can induce anti-glomerular basement membrane antibodies or antinuclear antibodies in rats and rabbits, resulting in severe autoimmune or immune complex glomerulonephritis ${ }^{2-4)}$. $\mathrm{HgCl}_{2}$ also induces antinucleolar autoantibodies (AnuA) in susceptible mice ${ }^{5-8)}$. These immunological abnormalities occur in a $\mathrm{T}$ cell dependent manner ${ }^{8-11)}$. The susceptibility to $\mathrm{HgCl}_{2}$ induced autoimmunity is mainly determined by the class II major histocompatibility complexes (MHC), though extra MHC genes may also be involved ${ }^{2,12-15)}$. In addition, $\mathrm{HgCl}_{2}$ increases the expression of class II MHC on B cells in rats and mice ${ }^{16-18)}$.

Sodium selenite $\left(\mathrm{Na}_{2} \mathrm{SeO}_{3}\right)$ protects against the toxicity of $\mathrm{HgCl}_{2}$. Necrotizing changes of renal tubules caused by $\mathrm{HgCl}_{2}$ toxicity completely disappeared after the administration of $\mathrm{Na}_{2} \mathrm{SeO}_{3}{ }^{19}$. Further, animals given a lethal dose of $\mathrm{HgCl}_{2}$ together with $\mathrm{Na}_{2} \mathrm{SeO}_{3}$ survived with few pathological changes ${ }^{19,}{ }^{20}$. However, its effect on autoimmunity induction by $\mathrm{HgCl}_{2}$ had not yet been studied. Thus, we performed the present experiments.

IQI/Jcl mice were obtained from the Central Institute for Experimental Animals (Kawasaki, Japan), and were maintained in our own animal facilities under conventional conditions. Both male and female mice were supplied for the experiments at 8 to 10 weeks old.

Stock solutions of $10 \mathrm{mg} / \mathrm{ml}$ of $\mathrm{HgCl}_{2}$ (Wako Pure Chemical, Tokyo, Japan) and $\mathrm{Na}_{2} \mathrm{SeO}_{3}$ (Wako Pure Chemical, Tokyo, Japan) in sterile $0.9 \%$ saline were prepared 
at the beginning of each experiment. Before administration, aliquot of the stock solutions were diluted with sterile $0.9 \%$ saline to the desired concentrations. To avoid direct contact, mice simultaneously received subcutaneous injection of 0.1 $\mathrm{ml} \mathrm{HgCl} 2$ solution and intraperitoneal injection of $0.5 \mathrm{ml} \mathrm{Na} \mathrm{SeO}_{3}$ solution 3 times a week for 4 weeks. Control mice were given subcutaneous $0.1 \mathrm{ml}$ and/or intraperitoneal $0.5 \mathrm{ml}$ of $0.9 \%$ saline.

The mice were anesthetized with chloroform and then bled by heart puncture 2 days after the final injection. Sera were separated and stored at $-20^{\circ} \mathrm{C}$ until use. AnuA levels were determined by indirect immuno-fluorescence using rat myoid cells (R615B2) as the substrate and fluorescein-conjugated goat-anti-mouse IgG (Cappel, West Chester, PA, USA). The sera were diluted with phosphate buffered saline by a 2-fold dilution starting at 1:10. The AnuA titer was expressed as the number of the tube with the highest dilution showing the nucleolar staining. Details of the method were described previously ${ }^{8)}$.

Since $\mathrm{Na}_{2} \mathrm{SeO}_{3}$ can reduce the toxic effects of $\mathrm{HgCl}_{2}$ and its optimum suppressive effects occur when equimolar amounts are administered ${ }^{20)}$, equimolar amounts of $\mathrm{HgCl}_{2}$ and $\mathrm{Na}_{2} \mathrm{SeO}_{3}$ were injected at the first experiment. Repeated administration of $4 \mu$ mole $/ \mathrm{kg}(1.09 \mathrm{mg} / \mathrm{kg}) \mathrm{HgCl}_{2}$ induced high titer AnuA in all mice with and without injection of $4 \mu$ mole $/ \mathrm{kg}(0.69 \mathrm{mg} / \mathrm{kg}) \mathrm{Na}_{2} \mathrm{SeO}_{3}$ (Table 1). Injection of $\mathrm{Na}_{2} \mathrm{SeO}_{3}$ alone did not induce any AnuA. In the second experiment, the same amounts of metals were administered. Male mice were injected with 1 $\mathrm{mg} / \mathrm{kg} \mathrm{HgCl}_{2}(0.74 \mathrm{mg} / \mathrm{kg}$ as $\mathrm{Hg})$ and $1.84 \mathrm{mg} / \mathrm{kg} \mathrm{Na}_{2} \mathrm{SeO}_{3}(0.74 \mathrm{mg} / \mathrm{kg}$ as $\mathrm{Se})$, or $0.25 \mathrm{mg} / \mathrm{kg} \mathrm{HgCl}(0.19 \mathrm{mg} / \mathrm{kg}$ as $\mathrm{Hg})$ and $0.46 \mathrm{mg} / \mathrm{kg} \mathrm{Na}_{2} \mathrm{SeO}_{3}(0.19 \mathrm{mg} / \mathrm{kg}$ as $\mathrm{Se}$ ), respectively. Once again, $\mathrm{Na}_{2} \mathrm{SeO}_{3}$ did not inhibit AnuA induction by $\mathrm{HgCl}_{2}$ (Table 2).

In these experiments, neither simultaneous injection with equimolar $\mathrm{Na}_{2} \mathrm{SeO}_{3}$ nor amounts of Se equivalent to $\mathrm{Hg}$ reduced AnuA induction by $\mathrm{HgCl}_{2}$. These results

Table 1. Effects of $\mathrm{Na}_{2} \mathrm{SeO}_{3}$ on $\mathrm{AnuA}$ induction by $\mathrm{HgCl}_{2}$ (I).

\begin{tabular}{clcc}
\hline Sex & \multicolumn{1}{c}{ Treatment } & Positive/Examined & Titer \\
\hline Male & Saline + Saline & $0 / 8$ & \\
& Saline $+\mathrm{Na}_{2} \mathrm{SeO}_{3}$ & $0 / 8$ & \\
& $\mathrm{HgCl}_{2}+\mathrm{Saline}$ & $8 / 8$ & $7.5 \pm 0.9$ \\
& $\mathrm{HgCl}_{2}+\mathrm{Na}_{2} \mathrm{SeO}_{3}$ & $10 / 10$ & $7.5 \pm 0.5$ \\
& & & \\
& Faline $+\mathrm{Saline}$ & $0 / 7$ & \\
& $\mathrm{Saline}+\mathrm{Na}_{2} \mathrm{SeO}_{3}$ & $0 / 7$ & $6.7 \pm 1.5$ \\
& $\mathrm{HgCl}_{2}+\mathrm{Saline}$ & $7 / 7$ & $7.6 \pm 0.5$ \\
\hline
\end{tabular}

$4 \mu \mathrm{mol} / \mathrm{kg} \mathrm{HgCl}{ }_{2}(0.1 \mathrm{ml} / \mathrm{mouse}$, s.c. $)$ and $/$ or $4 \mu \mathrm{mole} / \mathrm{kg} \mathrm{Na}_{2} \mathrm{SeO}_{3}(0.5 \mathrm{ml} / \mathrm{mouse}$, i.p. $)$ were injected 3 times a week for 4 weeks. 
Table 2. Effects of $\mathrm{Na}_{2} \mathrm{SeO}_{3}$ on AnuA induction by $\mathrm{HgCl}_{2}$ (II).

\begin{tabular}{cccc}
\hline $\mathrm{HgCl}_{2}(\mathrm{mg} / \mathrm{kg})$ & $\mathrm{Na}_{2} \mathrm{SeO}_{3}(\mathrm{mg} / \mathrm{kg})$ & Positive/Examined & Titer \\
\hline 0 & 0 & $0 / 8$ & \\
& 0.46 & $0 / 8$ & \\
& 1.84 & $0 / 8$ & $6.4 \pm 1.1$ \\
0.25 & 0 & $8 / 8$ & $5.9 \pm 0.9$ \\
& 0.46 & $8 / 8$ & $6.0 \pm 1.0$ \\
\multirow{2}{*}{1.0} & 0 & $8 / 8$ & $5.7 \pm 1.0$ \\
& 1.84 & $7 / 7$ & \\
\hline
\end{tabular}

$\mathrm{HgCl}_{2}(0.1 \mathrm{ml} / \mathrm{mouse}$, s.c. $)$ and $\mathrm{Na}_{2} \mathrm{SeO}_{3}(0.5 \mathrm{ml} /$ mouse, i.p. $)$ were injected in male mice 3 times a week for 4 weeks.

suggested that the pathological mechanism of autoimmunity induction by $\mathrm{HgCl}_{2}$ might be independent of its toxicity. Since doses of $\mathrm{HgCl}_{2}$ necessary to induce AnuA were far less than those to induce toxic effects, it might also be possible that doses of $\mathrm{Na}_{2} \mathrm{SeO}_{3}$ used in these experiments were too small to inhibit autoimmunity induction by $\mathrm{HgCl}_{2}$.

The possible mechanism(s) of autoimmunity induced by heavy metals and chemicals may include (1) release of autoantigen(s) in the circulation due to their toxic effects; (2) alteration of autoantigen(s) due to their combination with self antigen(s); or (3) direct effects on lymphocytes following activation of helper $\mathrm{T}$ cells and subsequent polyclonal activation of $\mathrm{B}$ cells ${ }^{2,21,22)}$. The precise mechanism of AnuA induction by $\mathrm{HgCl}_{2}$ requires further examination.

\section{REFERENCES}

1) Kazantzis G. Hypersensitivity: Clinical aspects. in Dayan AD, Hertel RF, Heseltine E, Kazantzis G, Smith EM, Van der Venne MT eds. Immunotoxicity of metals and immunotoxicology. Plenum Publishing Corporation, New York, 1990; 67-74.

2) Pelletier L, Castedo M, Bellon B, Druet P. Mercury and autoimmunity. in Dean JH, Luster MI, Munson AE, Kimber I eds. Immunotoxicology and immunopharmacology (second edition). Raven Press, New Tork, 1994; 539-52.

3) Weening JJ, Fleuren GJ, Hoedmaeker PhJ. Demonstration of antinuclear antibodies in mercuric chloride- induced glomerulopathy in the rats. Lab Invest 1978; 39: 405-11.

4) Roman-Franco A, Turiello M, Albine B. Ossi E, Milgrom F, Andres GA. Anti-basement membrane antibodies and antigen-antibody complexes in rabbit injected with mercuric chloride. Clin Immunol Immunopathol 1978; 9: 464-81.

5) Robinson CJG, Abraham AA, Balazs T. Induction of antinuclear antibodies by mercuric chloride in mice. Clin Exp Immunol 1984; 58: 300-6.

6) Hultman P, Enestrom S. Mercury induced antinuclear antibodies in mice: Characterization and correlation with renal immune complex deposits. Clin Exp Immunol 1988; 71: 269-74.

7) Reutter R, Tessars G, Vohr HW, Gleichmann E, Luhrmann R. Mercuric chloride induces autoantibodies against U3 small nuclear ribonucleoprotein in susceptible mice. Proc Natl Acad Sci USA $1989 ; 86: 337-41$.

8) Saegusa J, Yamamoto S, Iwai H, Ueda K. Antinucleolar autoantibody induced in mice by mercuric 
chloride. Ind Health 1990; 28: 21-30.

9) Pelletier L, Pasquire R, Hirsch F, Sapin C, Rossert J, Druet P. Autoreactive T cells in mercuryinduced autoimmune disease: in vitro demonstration. J Immunol 1986; 137: 2548-54.

10) Pelletier L, Pasquire R, Rossert J, Vial MC, Mandet C, Druet P. Autoreactive T cells in mercuryinduced autoimmunity. Ability to induce the autoimmune disease. J Immunol 1988; 140: 750 4.

11) Hultman P, Enestrom S. Murine mercury-induced immune-complex disease: Effect of cyclophosphamide treatment and importance of T cells. Brit J Exp Pathol 1989; 70: 227-36.

12) Robinson CJG, Balazs T, Egorov IK. Mercuric chloride-, gold sodium thiomate, and d-penicillamine-induced antunuclear antibodies in mice. Toxicol Appl Pharmacol 1986; 86: 159-69.

13) Kolb H, Toyka KV, Gleichmann E. Histocompatibility antigens and chemical reactivity in autoimmunity. Immunol Today 1987; 8: 3-6.

14) Saegusa J, Kiuchi Y, Itoh T. Antinucleolar autoantibody induced in mice by mercuric chloride: Strain difference in susceptibility. Exp Anim 1990; 39: 597-9.

15) Saegusa J, Kubota H, Kiuchi Y. Antinucleolar autoantibody induced in mice by mercuric chloride: A genetic study. Ind Health 1991; 29: 167-70.

16) Atten J, Bosman CB, Rozing J, Stijnen T, Hoedemaeker PhJ, Weening JJ. Mercuric chlorideinduced autoimmunity in the Brown Norway rat. Cellular kinetic and major histocompatibility complex antigen expression. Am J Pathol 1988; 133: 127-38.

17) Dubey C, Bellon F, Hirsch F, Kuhn J, Vial MC, Goldman M, Druet P. Increased expression of class II major histocompatibility complexes molecules on $\mathrm{B}$ cells in the rats susceptible or resistant to $\mathrm{HgCl}_{2}$-induced autoimmunity. Clin Exp Immunol 1991; 86: 118-23.

18) van Vliet E, Uhrberg M, Stein C, Gleichmann E. MHC control of IL-4-dependent enhancement of B cell Ia expression and Ig class switching in mice treated with mercuric chloride. Int Arch Allergy Immnol 1993; 392-401.

19) Parizek J, Ostadalova I. The protective effect of small amounts of selenite in sublimate intoxication. Experientia 1967; 23: 142-3.

20) Magos L, Webb M. The interaction of selenium with cadmium and mercury. CRC Crit Rev Toxicol 1980; 8: 1-41.

21) Bigazzi PE. Mechanisms of chemical-induced autoimmunity. in Dean JH, Luster MI, Munson $\mathrm{AE}, \mathrm{Amos} \mathrm{H}$ eds. Immnotoxicology and Immunopharmacology Raven press, New York 1985; 277-90.

22) Goldman M, Druet $P$, Gleichmann E. TH2 cells in systemic autoimmunity: insights from allogenic diseases and chemically induced autoimmunity. Immunol Today 1991; 12: 223-7.

National Institute of Industrial Health,

Junzo SAEGUSA and

21-1, Nagao 6-chome, Tama-ku,

Hisaya KUBOTA

Kawasaki 214, Japan

(Received October 19, 1995 and in revised form December 4, 1995) 